\title{
Patterns in the distribution of macrofaunal communities in coral reef sediments on the central Great Barrier Reef*
}

\author{
Martin J. Riddle \\ Australian Institute of Marine Science, PMB No. 3, Townsville, Queensland 4810, Australia
}

\begin{abstract}
The sediment environment and fauna from 6 reefs in a broad transect across the central Great Barrier Reef were quantitatively surveyed. Four distinct sediment types were present. Two were only found on the inner-shelf reefs; both contained high levels of silt/clay. The sediment from the more exposed inner-shelf site contained significant amounts of broken shell. The others were almost exclusively reef derived carbonates from middle and outer shelf reefs. One was predominantly coarse sand and gravel from the shallow reef flat, the other mainly medium to fine sand from the lagoon. There were major differences in the fauna trom the inner, middle and outer shelf reefs, whereas the fauna from different depth zones and sediment types within reefs showed less extreme differences. Contrary to expectation, sediments of similar type from the middle and outer shelf reefs did not support similar infaunal communities. Crustaceans (particularly amphipods), which were a significant component on the middle shelf reefs, were a very minor part of the sediment fauna on the outer shelf. Small changes in the sediment fauna occured over periods of a few months to a year, but major patterns persisted throughout the year. It is suggested that differences are maintained by a combination of mechanisms; larval availability (determined by water currents) interacts with habitat selection and differential survival. The short generation times and variety of life history tactics of sediment animals predispose this component of the reef fauna as a tool for the study of recruitment on coral reefs.
\end{abstract}

\section{INTRODUCTION}

Carbonate sediments on coral reefs typically cover a greater area than do hard substrata (Thomassin 1978). Lagoons represent up to $70 \%$ of the area enclosed by some middle shelf reefs on the central Great Barrier Reef (GBR) and are major sinks for organic detritus (Hatcher 1983). Despite the considerable research effort in the sediment ecology of other marine systems, the ecology of coral reef sediments has been virtually ignored. The few published studies have generally been restricted by locality (Faubel 1984, a single transect on one island), by taxa (Bailey-Brock 1976, tubicolous polychaetes) or most frequently by both locality and taxa (Kohn \& Lloyd 1973, polychaetes from a single sample from Easter Island; Reicheit 1979, polychaetes of Heron Island; Jones 1984, Crustacea of Lizard Island; Alongi 1986, nematodes of Davies Reef GBR). Certain localities have been studied at the community

\footnotetext{
- Contribution No. 421 from the Australian Institute of Marine Science
}

level, notable amongst these are Enewetak atoll (Harrison 1986), Discovery Bay, Jamaica (Aller \& Dodge 1974), the Tulear region in Madagascar (Guérin-Ancey 1970, Thomassin et al. 1976. Thomassin 1978) and the southwest lagoon of New Caledonia (Chardy et al 1987). None of these studies has compared sediment fauna from reefs under different environmental conditions and no broad-scale studies of the sediment fauna from the GBR have been published.

Throughout its length the GBR is subject to a significant environmental gradient from nearshore to the edge of the continental shelf. A transect of reefs along this gradient has been the basis for a concerted effort to characterize the broad-scale distribution patterns of coral reef biota (hard corals: Done 1982; soft corals: Dinesen 1983; sponges: Wilkinson \& Trott 1985; holothurians: Hammond et al. 1985; fishes: Williams 1982, 1983, Williams \& Hatcher 1983, Russ 1984a, b) and to understand their regulatory mechanisms. This study extends that theme to the fauna of reef sediments and focuses on 3 levels of spatial variability: (1) among reefs at various positions along a nearshore/offshore 
(cross-shelf) transect of reefs; (2) among reefs at similar positions on a cross-shelf transect; (3) among zones within reefs.

Temporal variability in community structure was also considered. The animals of sediments are mostly small with relatively short generation times (weeks to months; Santos \& Simon 1980), and the fauna of tropical sediments have faster turnover rates than those of temperate areas (Ansell et al. 1978), so reef sediments were sampled at intervals throughout a year to determine the persistence of observed characteristics.

\section{MATERIALS AND METHODS}

Study sites. The study was conducted on 6 reefs in 2 transects across the continental shelf in the central region of the Great Barrier Reef (Fig. 1). Each transect consisted of 1 inner shelf reef (Pandora or Phillips) located ca $18 \mathrm{~km}$ from the coast, 1 middle shelf reef (Rib or Lodestone) ca $70 \mathrm{~km}$ from the coast and 1 reef on the outer edge of the continental shelf (Myrmidon or Dip) ca $110 \mathrm{~km}$ offshore.

Within each reef 3 or 4 sites were sampled representing the different sediment environments (Table 1). Sites were placed at intervals along the gradient of wave energy from shallow windward reef flat to deep leeward lagoon (Fig. 2). On the inner shelf reefs, which have no distinct lagoon, sites were positioned on the windward and leeward sides according to the prevailing southeast trade wind.
To determine whether distribution patterns were persistent over time all sites from 1 transect of 3 reefs (Pandora, Rib and Myrmidon) were sampled on 4 occasions at $\mathrm{ca} 3 \mathrm{mo}$ intervals throughout 1 yr (July, November, February and May). The second transect of 3 reefs (Phillips, Lodestone and Dip) was sampled on 1 occasion (November) to determine whether the distribution patterns were representative of a more general trend.

Summaries of the gross morphology and physical environment of the study reefs are to be found in Done (1982).

Sampling methods. Sediment samples were taken with a cylindrical PVC corer of $55 \mathrm{~mm}$ internal diameter which was pushed manually to a depth of 200 to 250 $\mathrm{mm}$ into the sediment. At each site 15 (1st sampling occasion) or 20 (all subsequent occasions) cores were collected for faunal analysis. One additional core was collected for analysis of sediment characteristics at each site on each occasion.

Sampling was designed to minimize the effects of local patchiness. Four sets ( 3 on the first occasion) of 5 cores were taken, each set was from an area about $1 \mathrm{~m}^{2}$ and the sets were spaced about $4 \mathrm{~m}$ apart. The 5 cores in each set were bulked to form the basic sample unit (119 $\left.\mathrm{cm}^{2}\right)$.

Faunal samples were washed on a $0.5 \mathrm{~mm}$ squaremeshed sieve, preserved in 10\% formalin solution in seawater and stained with Rose Bengal to aid sorting. Animals were separated from the sediment by flotation during repeated washings, the sediment residue being

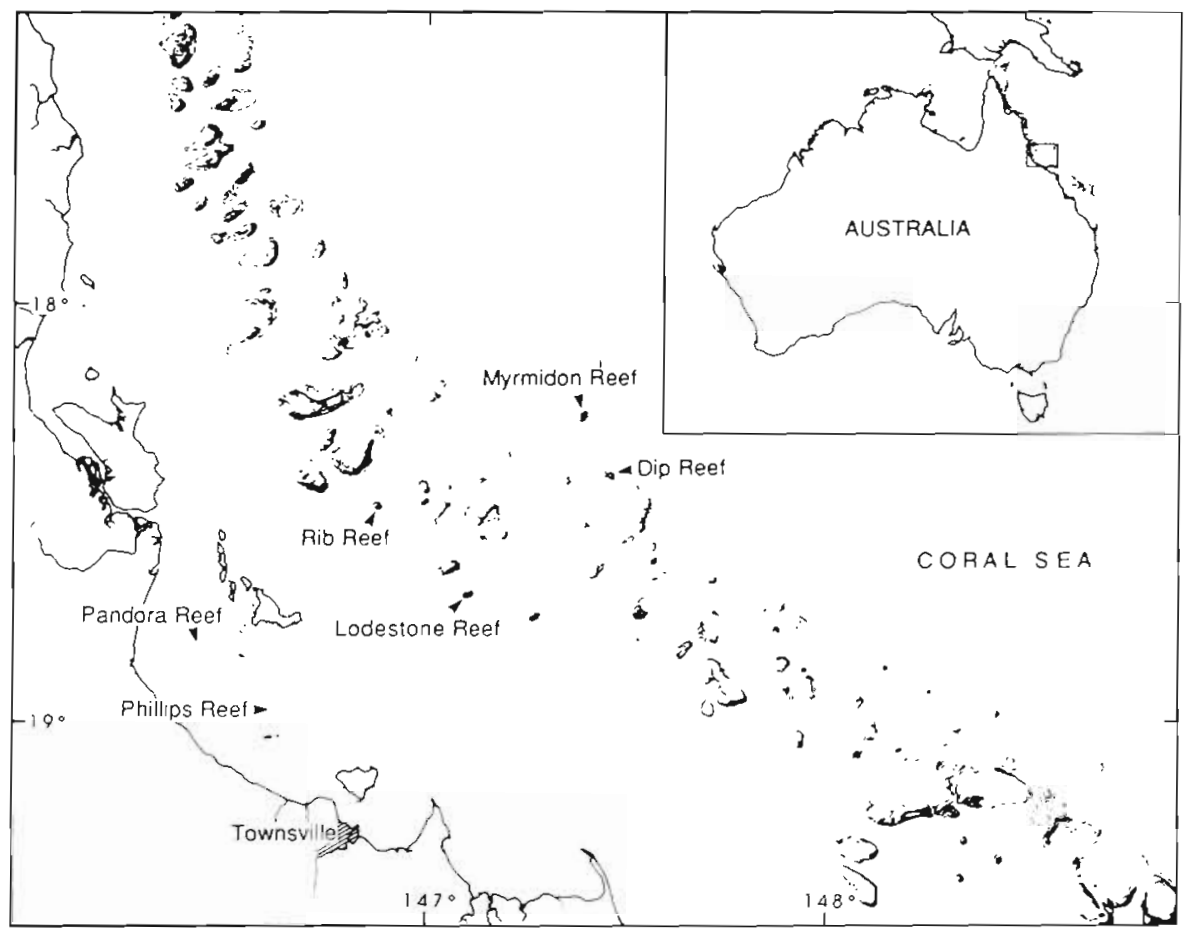

Fig. 1. Locations of study reefs on the central Great Barrier Reef 
Table 1. Description of sample sites

\begin{tabular}{|llcll}
\hline Locality (reefs sampled) & Site & Depth $(\mathrm{m})$ & \multicolumn{1}{c|}{ Site description } \\
\hline Inner shelf (Pandora & Windward slope & 15 & Corals scarce; epifauna abundant \\
and Phillips) & Reef flat & 1 & Coral rubble; dries on extreme tides (Pandora only) \\
& Leeward slope & 10 & Transition between coral and sediment cover (Pandora only) \\
& Deep leeward slope & 12 & Entirely sediment cover; epifauna scarce \\
Middle shelf & Reef flat & 2 & Sand patches enclosed by coral; sand ripples \\
(Rib and Lodestone) & Shallow lagoon & 4 & Sand dominant with coral outcrops; slight bioturbation \\
& Lagoon & 12 & Sand dominant with occasional coral; highly bioturbated \\
Outer shelf & Outer reef flat & 2 & Sand patches enclosed by coral; sand ripples \\
(Myrmidon and Dip) & Inner reef flat & 3 & Coral patches enclosed by sand; slight bioturbation \\
& Shallow lagoon & 7 & Sand dominant with occasional coral; moderate bioturbation \\
& Lagoon & 11 & (Myrimidon only) \\
& & & Sand dominant with occasional coral; highly bioturbated \\
\hline
\end{tabular}

finally checked under a dissecting microscope. Macrofaunal taxa were recorded to family level, representatives of 4 meiofaunal groups (Turbellaria, Nemertinea, Oligochaeta and Ostracoda) were commonly retained by the sieve and were identified to class.
Samples for sediment analyses were stored at $-18^{\circ} \mathrm{C}$. Grain size analysis followed the methods of Folk (1974). Total organic carbon analysis followed Sandstrom et al. (1986) using a Beckman Tocamaster Total Carbon Analyser. Total carbon and organic nitro-

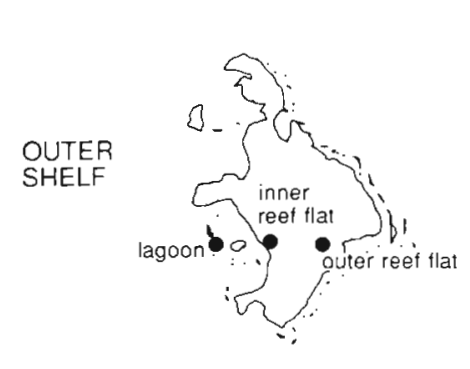

Dip Reef

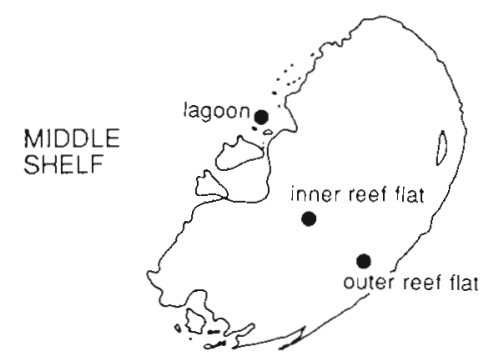

Lodestone Reef
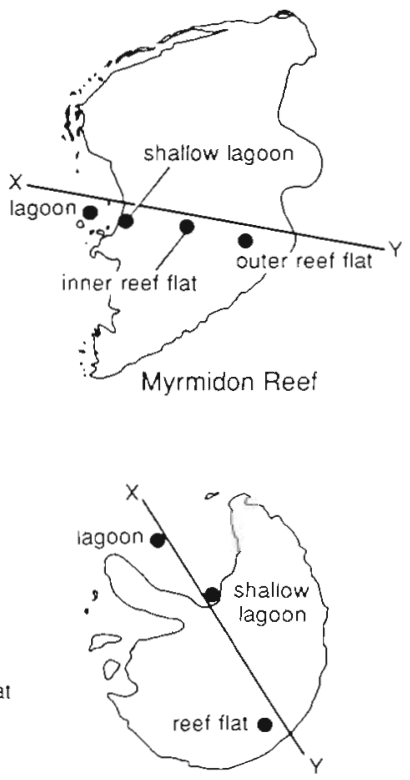

Rib Reef
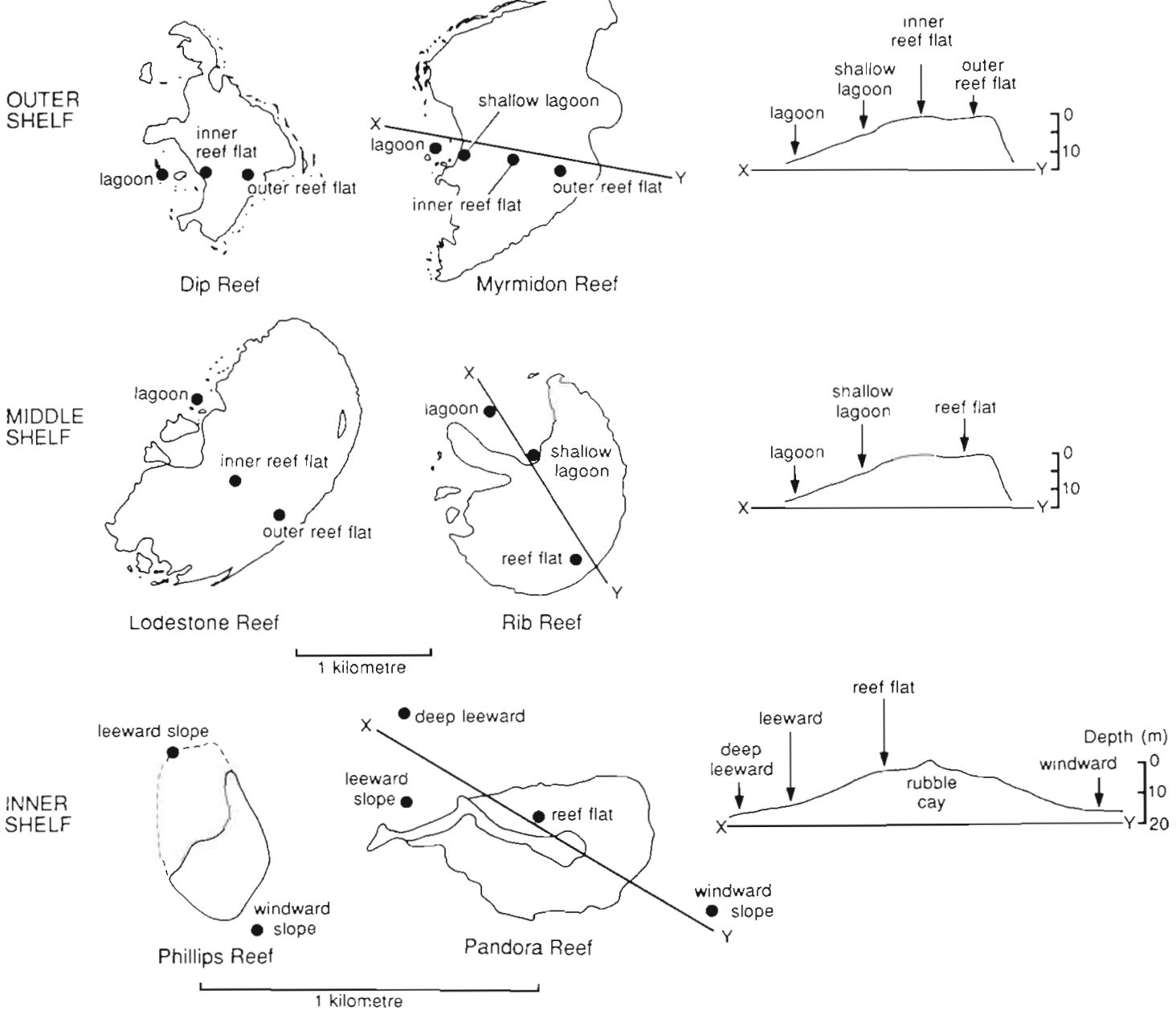

Fig. 2. Positions of sampling sites on reefs 
gen were measured on a Leco Model 600 CHN analyser. Calcium carbonate content was estimated by (Total C-Organic C) $\times 8.33$ (Sandstrom et al. 1986).

Data analyses. Agglomerative hierarchical classification (Williams 1971) was used to define relationships between sites based on both sediment characteristics and faunal composition. The Bray-Curtis similarity coefficient was used with Ward's incremental sum of squares fusion strategy. Faunal counts were $\log _{10}(x+$ 1) transformed before classification. Site groups were tested for significance using the Sandland \& Young $(1979 a$, b) procedure. The pseudo-Cramer value, $C$, was used to identify those taxa contributing most to the diagnosis of site groups (Abel et al. 1985). A data matrix of pooled sample units within a site and time was subjected to a principal co-ordinate analysis (Gower 1967) to further investigate the structure of groups produced by the classification. The classification, ordination and group diagnostic procedures are components of the PATN package (Belbin 1987).

\section{RESULTS}

\section{Numerical structure}

The size of animals represented in the sample ranged from 0.5 to $30 \mathrm{~mm}$. The sampling procedure excluded the large holothurians, which are a prominent feature of reef sediments, and the larger callianassid shrimps, responsible for the mounds ubiquitous on lagoon floors in the region.

A total of 36725 animals assigned to 154 taxa including representatives of 12 phyla were collected. Densities range from 3115 ind. $\mathrm{m}^{-2}$ at 1 site on Pandora Reef (inner shelf) to 43690 ind. $\mathrm{m}^{-2}$ at 1 site on Rib Reef (middle shelf). The fauna from the inner shelf reefs tends towards lower total counts but higher richness, diversity and evenness (at the family level) than the other reefs (Table 2). In comparison, the faunas of the middle and outer shelf reefs show dominance by a few taxa (low evenness), combined with slightly lower richness resulting in a general reduction of family diversity. Myrmidon (outer shelf) is notably depauperate in number of taxa. Richness and diversity at the other outer shelf reef, Dip, are comparable with those of the middle shelf reefs

\section{Classification of sites by sediments}

Four distinct sediment types were identified (Tables 3 and 4) and are characterized as follows (nomenclature after Folk 1974).

Gravelly muddy sand. This was found at the more exposed sites on the inner reefs and is characterized by significant levels of non-calcium carbonate material and by approximately equal levels of gravel, sand and silt/clay. It contains a large amount of broken shell contributing to the gravel fraction and to the $\mathrm{CaCO}_{3}$ content

Slightly gravelly sandy mud. This was found at the more sheltered sites on the inner shelf reefs and is characterized by high levels of non-calcium carbonate material, low levels of gravel and moderate levels of sand, with the majority of the sediment being silt/clay Levels of organic carbon and nitrogen are higher than in any other sediment type.

Gravelly sand. This was found at all the shallow sites on the middle and outer shelf reefs. A similar sediment was found at a very shallow site on the reef flat at Pandora (inner shelf). It is predominantly coarse sand ( 0.5 to $2 \mathrm{~mm}$ ) with a significant gravel ( $>2 \mathrm{~mm}$ ) content and very little silt/clay. These sediments are primarily traction load deposits, corresponding to sediment type I of Flood \& Orme (1977)

Sand. This was found at all the deeper sites on the middle and outer shelf reefs. It has low gravel and silt/ clay contents being predominantly medium to fine sand $(0.063$ to $0.5 \mathrm{~mm})$. This sediment is primarily saltation load with varying amounts of traction and/or suspension load, corresponding to sediment type III of Flood \& Orme (1977)

There is no clear demarcation between inter-reef and reef sediments on the inner shelf. The sediment is not primarily of reef origin and the location, high levels of non-calcium carbonate and high silt/clay content all suggest a significant terrestrial input. In contrast, both

Table 2. Numerical structure (mean for all sites and times within a locality with range in parentheses) of sediment fauna from reefs at different locations on the continental shelf (all except density are per total sample $\left[0.048 \mathrm{~m}^{2}\right]$ at each site/time combination)

\begin{tabular}{|lcccc|}
\hline Locality & $\begin{array}{c}\text { Density } \\
\left(\mathrm{m}^{-2}\right)\end{array}$ & $\begin{array}{c}\text { Number of } \\
\text { taxa }\end{array}$ & $\begin{array}{c}\text { Diversity (Shannon- } \\
\left.\text { Wiener } \log _{2}\right)\end{array}$ & $\begin{array}{c}\text { Evenness } \\
\text { (Pièlou) }\end{array}$ \\
\hline Inner shelf & $9197(3115-15174)$ & $47(32-70)$ & $4.27(2.96-5.07)$ & $0.77(0.59-0.87)$ \\
Middle shelf & $21614(10186-43690)$ & $42(27-57)$ & $3.49(2.24-4.48)$ & $0.65(0.42-0.77)$ \\
Outer shelf & $12922(5451-43669)$ & $28(18-44)$ & $2.77(1.79-4.13)$ & $0.58(0.43-0.77)$ \\
\hline
\end{tabular}


Table 3. Sediment grain size characteristics (mean \pm SE) from zones on reefs in a transect across the central GBR

\begin{tabular}{|c|c|c|c|c|c|c|c|}
\hline Locality & Site & $\begin{array}{c}\text { Gravel } \\
>2 \mathrm{~mm} \\
\%(w t / w t)\end{array}$ & $\begin{array}{c}\text { Coarse sand } \\
0.5-2 \mathrm{~mm} \\
\%(w t / w t)\end{array}$ & $\begin{array}{c}\text { Medium/fine } \\
\text { sand } \\
0.063-0.5 \mathrm{~mm} \\
\% \text { (wt } / w \mathrm{t})\end{array}$ & $\begin{array}{c}\text { Silt/clay } \\
<0.063 \mathrm{~mm} \\
\% \text { (wt } / \mathrm{wt})\end{array}$ & Phi mean & $\begin{array}{l}\text { Sorting } \\
\text { coefficient }\end{array}$ \\
\hline \multirow[t]{4}{*}{ Inner shelf } & $\begin{array}{l}\text { Windward slope } \\
\quad n=5\end{array}$ & $25 \pm 5$ & $31 \pm 7$ & $18 \pm 5$ & $26 \pm 6$ & $1.6 \pm 0.6$ & $3.0 \pm 0.10$ \\
\hline & $\begin{array}{l}\text { Reef flat } \\
\quad n=1\end{array}$ & 27 & 58 & 13 & 2 & 2 & 1.8 \\
\hline & $\begin{array}{l}\text { Leeward slope } \\
\quad n=4\end{array}$ & $1 \pm 0.7$ & $4 \pm 1.5$ & $38 \pm 6$ & $57 \pm 4$ & $4.7 \pm 0.06$ & $2.3 \pm 0.10$ \\
\hline & $\begin{array}{l}\text { Deep leeward } \\
\text { slope } \\
\quad n=4\end{array}$ & $1 \pm 0.7$ & $2 \pm 1.0$ & $36 \pm 3$ & $61 \pm 2$ & $4.8 \pm 0.04$ & $2.0 \pm 0.16$ \\
\hline \multirow[t]{3}{*}{ Middle shelf } & $\begin{array}{c}\text { Reef flat } \\
\quad n=4\end{array}$ & $21 \pm 5$ & $53 \pm 11$ & $24 \pm 6$ & $2 \pm 0.4$ & $0.1 \pm 0.16$ & $1.6 \pm 0.14$ \\
\hline & $\begin{array}{l}\text { Shallow lagoon } \\
\qquad n=7\end{array}$ & $<1 \pm 0.4$ & $30 \pm 7$ & $69 \pm 7$ & $<1 \pm 0.2$ & $1.6 \pm 0.16$ & $1.4 \pm 0.11$ \\
\hline & $\begin{array}{l}\text { Lagoon } \\
\quad n=6\end{array}$ & $<1 \pm 0.3$ & $15 \pm 5$ & $81 \pm 5$ & $3 \pm 0.7$ & $2.1 \pm 0.17$ & $1.5 \pm 0.02$ \\
\hline \multirow[t]{4}{*}{ Outer shelf } & $\begin{array}{l}\text { Outer reef flat } \\
\quad n=6\end{array}$ & $20 \pm 3$ & $54 \pm 6$ & $25 \pm 4$ & $1 \pm 0.7$ & $0.1 \pm 0.12$ & $1.5 \pm 0.16$ \\
\hline & $\begin{array}{l}\text { Inner reef flat } \\
\quad n=5\end{array}$ & $11 \pm 1$ & $52 \pm 2$ & $35 \pm 2$ & $2 \pm 0.3$ & $0.6 \pm 0.08$ & $1.6 \pm 0.06$ \\
\hline & $\begin{array}{l}\text { Shallow lagoon } \\
\quad n=4\end{array}$ & $1 \pm 0.6$ & $22 \pm 2$ & $75 \pm 2$ & $2 \pm 0.3$ & $1.7 \pm 0.11$ & $1.4 \pm 0.06$ \\
\hline & $\begin{array}{l}\text { Deep lagoon } \\
\quad n=4\end{array}$ & $<1 \pm 0.2$ & $29 \pm 4$ & $70 \pm 4$ & $<1 \pm 0.1$ & $1.8 \pm 0.30$ & $1.1 \pm 0.06$ \\
\hline
\end{tabular}

Table 4. Levels of organic carbon, organic nitrogen and calcium carbonate (mean $\pm S E$ ) in sediment from zones on reefs in a transect across the central GBR

\begin{tabular}{|c|c|c|c|c|}
\hline Locality & Site & $\begin{array}{c}\text { Organic carbon } \\
\%(w t / w t)\end{array}$ & $\begin{array}{c}\text { Organic nitrogen } \\
\%(w t / w t)\end{array}$ & $\begin{array}{c}\text { Calcium carbonate } \\
\%(w t / w t)\end{array}$ \\
\hline \multirow[t]{4}{*}{ Inner shelf } & $\begin{array}{l}\text { Windward slope } \\
\quad n=5\end{array}$ & $0.31 \pm 0.04$ & $0.06 \pm 0.007$ & $62 \pm 7.8$ \\
\hline & $\begin{array}{l}\text { Reef flat } \\
\quad n=1\end{array}$ & 0.21 & 0.08 & 93 \\
\hline & $\begin{array}{l}\text { Leeward slope } \\
\qquad n=4\end{array}$ & $0.66 \pm 0.04$ & $0.14 \pm 0.008$ & $54 \pm 1.7$ \\
\hline & $\begin{array}{l}\text { Deep leeward slope } \\
\quad n=4\end{array}$ & $0.53 \pm 0.02$ & $0.10 \pm 0.006$ & $51 \pm 2.5$ \\
\hline \multirow[t]{3}{*}{ Middle shelf } & $\begin{array}{c}\text { Reef flat } \\
n=4\end{array}$ & $0.26 \pm 0.01$ & $0.06 \pm 0.021$ & $96 \pm 0.1$ \\
\hline & $\begin{array}{l}\text { Shallow lagoon } \\
\quad n=7\end{array}$ & $0.23 \pm 0.01$ & $0.06 \pm 0.012$ & $96 \pm 0.2$ \\
\hline & $\begin{array}{l}\text { Lagoon } \\
\qquad n=6\end{array}$ & $0.23 \pm 0.02$ & $0.07 \pm 0.010$ & $95 \pm 0.3$ \\
\hline \multirow[t]{4}{*}{ Outer shelf } & $\begin{array}{l}\text { Outer reef flat } \\
\quad n=6\end{array}$ & $0.22 \pm 0.01$ & $0.07 \pm 0.008$ & $96 \pm 0.2$ \\
\hline & $\begin{array}{l}\text { Inner reef flat } \\
\quad n=5\end{array}$ & $0.22 \pm 0.01$ & $0.07 \pm 0.015$ & $96 \pm 0.3$ \\
\hline & $\begin{array}{c}\text { Shallow lagoon } \\
n=4\end{array}$ & $0.22 \pm 0.01$ & $0.06 \pm 0.011$ & $96 \pm 0.2$ \\
\hline & $\begin{array}{l}\text { Lagoon } \\
\qquad n=5\end{array}$ & $0.22 \pm 0.01$ & $0.07 \pm 0.018$ & $96 \pm 0.3$ \\
\hline
\end{tabular}


sediment types found predominantly on the middle and outer shelf reefs are almost entirely of reef derived material (95 to $96 \% \mathrm{CaCO}_{3}$ ).

\section{Classification of sites by fauna}

The classification produced almost perfect correspondence between the chosen habitats and the faunal assemblages. At the 7 group level, sites grouped at 2 distinct levels of similarity (Fig. 3). The greatest differ-

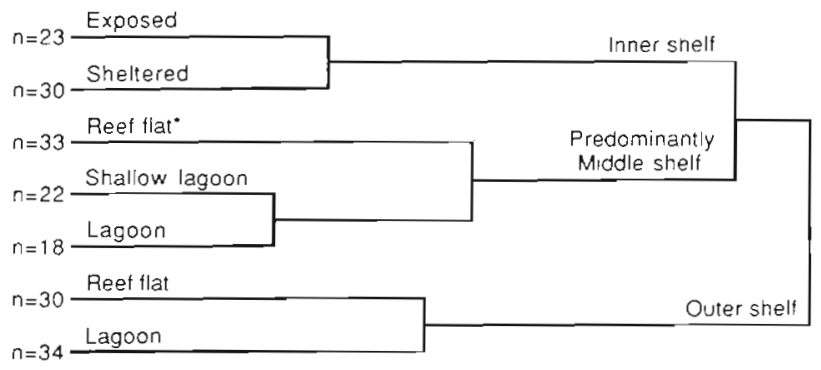

Fig. 3. Dendrogram of classification of sites by fauna] composition $\left[\log _{10}(x+1)\right.$ transformed data, Bray-curtis similarity. Ward's incremental sum of squares fusion]. 'Group of middle shelf reef flat sites includes the reef flat on Pandora Reef and the reef flat and shallow lagoon sites on Dip Reef

ences in fauna are between reefs at different positions on the continental shelf. At this level sites are split into 3 groups (inner shelf sites, predominantly middle shelf sites and outer shelf sites). The reef flat site from Pandora was the only inner shelf site not to conform to this general plan, being most similar to the reef flat sites on middle shelf reefs. The reef flat and shallow lagoon sites from Dip Reef (outer shelf) did not form a group with the corresponding sites on Myrmidon, instead they were more similar to the reef flat sites from the middle shelf.

The second level (Fig. 3) separates zones within reefs corresponding to the different environmental conditions found.

\section{Faunal composition of site groups}

A list of all taxa and their mean densities at each of the 7 site groups has been published (Riddle 1988).

Polychaetes constituted the largest component of the fauna overall (Fig. 4) and, as a consequence of high numbers of syllids, errant polychaetes outnumbered sedentary polychaetes at all sites except on the inner shelf reefs and in the lagoon on the middle shelf. Crustacea were the second most abundant group overall and constituted the largest component of the fauna from lagoons on middle shelf reefs. Amphipods were the most abundant single group of crustaceans at all sites except on the outer shelf reefs, where they were in very low numbers. Molluscs were not found in dense populations at any site. Bivalves showed their greatest diversity on the inner shelf, the gastropods on the middle shelf. Tellinids were the only family of bivalve widely represented on the middle and outer shelf reefs. The larger contribution by the group 'other taxa' on the middle and outer shelf reefs (Fig. 4) represents high counts of oligochaetes. The echinoderms (included in 'other taxa') were not very abundant at any site; the highest counts were of ophiuroids on the more exposed inner reef site and fibularian echinoids on middle shelf reef flats. Branchiostomids were also included in this group and were most abundant in the sands of shallow lagoons on the middle shelf.

Syllids were ranked in the 3 most abundant taxa at all except the more sheltered sites on the inner shelf (Table 5). They were the only taxon found at every site on all sampling occasions and contribute $27 \%$ of the total count. The sedentary polychaete families Spionidae, Paraonidae and Capitellidae were found at all sites and were within the most abundant taxa at many sites. Tanaids, ostracods and oligochaetes were ranked highly at mast sites; however, as these divisions each represent several families they are not directly comparable with the groups separated to family.

Many of the top ranking families were ubiquitous and of little help in distinguishing sites, although the high pseudo-Cramer value for syllids (Table 6) indicated that differences in their densities at different sites were characteristic. Several lesser ranked taxa were characteristic of particular site groups (Table 6). The sedentary polychaete family Cossuridae and the bivalve family Semelidae were characteristic of the

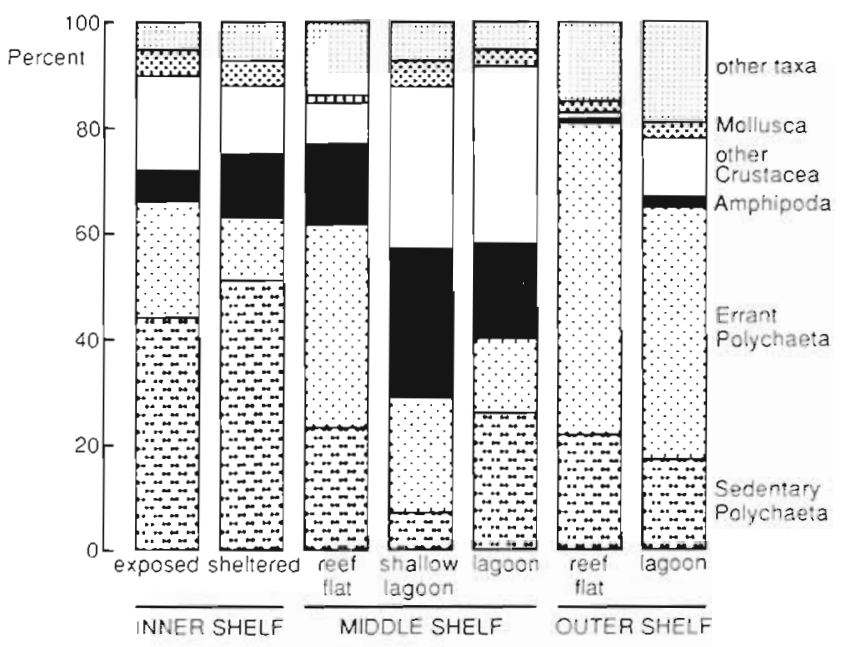

Fig. 4. Composition (\%), by major taxonomic divisions, of sites grouped by classification 
Table 5. The 10 most abundant taxa in coral reef sediments from different locations on the central GBR, their mean density ( $\mathrm{m}^{-2}$, average for all samples and times) and their percentage of the total count. Site groups were determined by classification (Fig. 3)

\begin{tabular}{|c|c|c|c|c|c|c|c|c|c|}
\hline \multicolumn{10}{|c|}{ Inner shelf } \\
\hline \multicolumn{4}{|c|}{ Exposed windward slope $(n=23)$} & \multicolumn{6}{|c|}{ Sheltered leeward slope $(n=30)$} \\
\hline & & $m^{-2}$ & $\%$ & & & $m^{-2}$ & & $\%$ & \\
\hline Syllidae & & 1098 & 11 & \multicolumn{2}{|c|}{ Spionidae } & 1532 & \multicolumn{3}{|c|}{19} \\
\hline Maldanidae & & 1007 & 10 & \multicolumn{2}{|c|}{ Cirratulidae } & 895 & \multicolumn{3}{|c|}{11} \\
\hline Spionidae & & 769 & 8 & \multicolumn{2}{|c|}{ Paraonidae } & 609 & \multicolumn{3}{|c|}{7} \\
\hline Ostracoda & & 692 & 7 & \multicolumn{2}{|c|}{ Capitellidae } & 544 & \multicolumn{3}{|c|}{7} \\
\hline Paraonidae & & 615 & 6 & \multicolumn{2}{|c|}{ Oligochaeta } & 368 & \multicolumn{3}{|c|}{4} \\
\hline Tanaidacea & & 498 & 5 & \multicolumn{2}{|c|}{ Oedicerotidae } & 337 & \multicolumn{3}{|c|}{4} \\
\hline Capitellidae & & 428 & 4 & \multicolumn{2}{|c|}{ Tanaidacea } & 309 & \multicolumn{3}{|c|}{4} \\
\hline Oweniidae & & 381 & 4 & \multicolumn{2}{|c|}{ Gammaridae } & 289 & \multicolumn{3}{|c|}{4} \\
\hline Amphiuridae & & 271 & 3 & \multicolumn{2}{|c|}{ Nephtyidae } & 286 & \multicolumn{3}{|c|}{3} \\
\hline Palmyridae & & 267 & 3 & \multicolumn{2}{|c|}{ Phoxocephalidae } & 269 & \multicolumn{3}{|c|}{3} \\
\hline \multicolumn{10}{|c|}{ Middle shelf } \\
\hline \multicolumn{3}{|c|}{ Reef flat $(n=33)$} & Shallow 1 & $(n=2$ & & Lagoor & $=18)$ & & \\
\hline & $\mathrm{m}^{-2}$ & $\%$ & & $m^{-2}$ & $\%$ & & $m^{-2}$ & & $\%$ \\
\hline Syllidae & 6130 & 32 & Ostracoda & 6080 & 22 & Ostracoda & 3737 & & 17 \\
\hline Oligochaeta & 2689 & 13 & Syllidae & 5100 & 19 & Oweniidae & 2886 & & 13 \\
\hline Gammaridae & 1872 & 8 & Phoxocephalidae & 3405 & 12 & Syllidae & 1403 & & 6 \\
\hline Phoxocephalidae & 837 & 3 & Dexaminidae & 2855 & 10 & Diastylidae & 1062 & & 5 \\
\hline Spionidae & 826 & 3 & Spionidae & 1775 & 7 & Phoxocephalidae & 996 & & 5 \\
\hline Janiridae & 791 & 3 & Bodotriidae & 1060 & 4 & Spionidae & 940 & & 4 \\
\hline Paraonidae & 546 & 3 & Tellinidae & 972 & 4 & Oligochaeta & 907 & & 4 \\
\hline Dexaminidae & 492 & 2 & Tanaidacea & 846 & 3 & Leuconidae & 790 & & 4 \\
\hline Ctenodrilidae & 454 & 2 & Oedicerotidae & 807 & 3 & Haustoriidae & 650 & & 3 \\
\hline Opheliidae & 365 & 2 & & 471 & 2 & Tanaidacea & 603 & & 3 \\
\hline & & & $\mathrm{Ou}$ & & & & & & \\
\hline & Reef flat & $(n=30$ & & & & Lagoon $(n=34)$ & & & \\
\hline & & $m^{-2}$ & $\%$ & & & $m^{-2}$ & & $\%$ & \\
\hline Syllidae & & 7024 & 55 & Syllid & & 5043 & & 43 & \\
\hline Oligochaeta & & 1841 & 14 & Oligo & haeta & 2079 & & 18 & \\
\hline Spionidae & & 1254 & 10 & Parao & idae & 889 & & 8 & \\
\hline Chaetopteridae & & 525 & 4 & Tana & acea & 822 & & 7 & \\
\hline Capitellidae & & 415 & 3 & Tellin & & 342 & & 3 & \\
\hline Paraonidae & & 286 & 2 & Spion & & 300 & & 3 & \\
\hline Amphinomidae & & 174 & 1 & Capit & lidae & 267 & & 2 & \\
\hline Maldanidae & & 154 & 1 & Dorvi & eidae & 255 & & 2 & \\
\hline Arenicolidae & & 146 & 1 & Ostra & & 196 & & 2 & \\
\hline Ostracoda & & 123 & 1 & Lumb & neridae & 188 & & 2 & \\
\hline
\end{tabular}

inner shelf reefs. Twenty-three other taxa were restricted to the inner shelf but were only taken occasionally and so are not considered characteristic at this sample size; they were: the caryophyllid coral Oryzotrochus stephensoni; the polychaetes Scalibregmidae, Goniadidae, Sternaspidae, Sabellariidae and Trichobranchidae; the amphipods Corophiidae and Stegocephalidae; pasiphaeid and upogebid shrimps; the crabs Goneplacidae and Cymonomidae; the chaetodermatid molluscs; the bivalve families Nuculidae, Glycymerididae, Condylocardiidae, Solenidae, Cultellidae, Corbullidae, Thraciidae and Cuspidaridae; the benthic chaetognath Spadellidae and the heart-urchin family Spatangidae. The tubedwelling polychaetes Sabellidae and Maldanidae and the brittle-star Amphiuridae were characteristic of windward sites on inner shelf reefs, while the freeliving sedentary polychaete Cirratulidae was consistently abundant in sheltered sites.

Three amphipod families, Dexaminidae, Phoxocephalidae and Liljeborgiidae were characteristically found on the middle shelf. Nineteen taxa were only found here but were not taken consistently enough to be considered characteristic; they were: the polychaetes Protodrilidae and Saccocirridae; the shrimp Processidae; the calappid $\mathrm{crab}_{\text {; }}$ the 2 chitons; the pro- 
Table 6. Density $\left(\mathrm{m}^{-2}\right.$ ) and standard error of taxa diagnostic (those with a high pseudo-Cramer value) of the 7 site groups from reefs in a transect across the central GBR. Boxes show those taxa with particularly high densities at that site group

\begin{tabular}{|c|c|c|c|c|c|c|c|}
\hline & \multicolumn{2}{|c|}{ Inner shelf } & \multicolumn{3}{|c|}{ Middle shelf } & \multicolumn{2}{|c|}{ Outer shelf } \\
\hline & $\begin{array}{c}\text { Exposed } \\
n=23\end{array}$ & $\begin{array}{c}\text { Sheltered } \\
n=30\end{array}$ & $\begin{array}{l}\text { Reef flat } \\
n=33\end{array}$ & $\begin{array}{c}\text { Shallow lagoon } \\
n=22\end{array}$ & $\begin{array}{l}\text { Lagoon } \\
n=18\end{array}$ & $\begin{array}{l}\text { Reef flat } \\
n=30\end{array}$ & $\begin{array}{l}\text { Lagoon } \\
n=34\end{array}$ \\
\hline Cossuridae & $11 \pm 8$ & $\overline{107 \pm 22}$ & 0 & 0 & 0 & 0 & 0 \\
\hline Semelidae & $143 \pm 41$ & $95 \pm 21$ & 0 & 0 & 0 & 0 & 0 \\
\hline Sabellidae & $242 \pm 38$ & $51 \pm 16$ & $7 \pm 4$ & 0 & $37 \pm 14$ & $3 \pm 3$ & $72 \pm 16$ \\
\hline Maldanidae & $1007 \pm 179$ & $109 \pm 27$ & $44 \pm 14$ & $61 \pm 32$ & $229 \pm 40$ & $154 \pm 42$ & $136 \pm 27$ \\
\hline Amphiuridae & $271 \pm 49$ & $34 \pm 15$ & $28 \pm 14$ & $4 \pm 4$ & $94 \pm 25$ & 0 & $12 \pm 5$ \\
\hline Cirratulidae & $154 \pm 38$ & $895 \pm 109$ & $47 \pm 13$ & $27 \pm 19$ & $164 \pm 36$ & $6 \pm 6$ & $45 \pm 10$ \\
\hline Dexaminidae & $26 \pm 12$ & $6 \pm 4$ & $463 \pm 96$ & $2855 \pm 890$ & $402 \pm 99$ & $14 \pm 10$ & $52 \pm 13$ \\
\hline Phoxocephalidae & $59 \pm 15$ & $269 \pm 58$ & $767 \pm 146$ & $3406 \pm 494$ & $996 \pm 177$ & 0 & $2 \pm 2$ \\
\hline Liljeborgiidae & $7 \pm 5$ & $8 \pm 6$ & $51 \pm 26$ & $172 \pm 45$ & $164 \pm 41$ & 0 & $5 \pm 3$ \\
\hline Gammaridae & $190 \pm 57$ & $289 \pm 83$ & $1726 \pm 446$ & $272 \pm 140$ & $346 \pm 217$ & $62 \pm 20$ & $5 \pm 3$ \\
\hline Tellinidae & $26 \pm 10$ & $101 \pm 26$ & $42 \pm 14$ & $846 \pm 294$ & $454 \pm 92$ & $22 \pm 7$ & $342 \pm 48$ \\
\hline Platyischnopidae & 0 & 0 & $9 \pm 6$ & $203 \pm 46$ & $571 \pm 126$ & 0 & 0 \\
\hline Ostracoda & $692 \pm 145$ & $208 \pm 56$ & $327 \pm 51$ & $6080 \pm 920$ & $3737 \pm 503$ & $123 \pm 34$ & $196 \pm 38$ \\
\hline Bodotriidae & $81 \pm 26$ & $45 \pm 13$ & $82 \pm 30$ & $972 \pm 233$ & $585 \pm 185$ & 0 & $10 \pm 7$ \\
\hline Oweniidae & $381 \pm 85$ & $22 \pm 13$ & $21 \pm 12$ & $15 \pm 15$ & $2886 \pm 665$ & 0 & $2 \pm 2$ \\
\hline Sigalionidae & $11 \pm 8$ & $14 \pm 6$ & 0 & $31 \pm 14$ & $140 \pm 34$ & 0 & 0 \\
\hline Diastylidae & $190 \pm 69$ & $60 \pm 22$ & $5 \pm 3$ & $19 \pm 8$ & $1062 \pm 344$ & 0 & $2 \pm 2$ \\
\hline Haustoridae & 0 & $59 \pm 24$ & $2 \pm 2$ & $15 \pm 9$ & $650 \pm 142$ & 0 & 0 \\
\hline Phtisicidae & 0 & 0 & 0 & $34 \pm 12$ & $201 \pm 39$ & $6 \pm 4$ & $17 \pm 7$ \\
\hline Syllidae & $1098 \pm 231$ & $146 \pm 32$ & $7258 \pm 1008$ & $5100 \pm 1158$ & $1403 \pm 192$ & $7024 \pm 666$ & $5043 \pm 584$ \\
\hline Nephtyidae & $172 \pm 47$ & $286 \pm 45$ & $2 \pm 2$ & $8 \pm 5$ & $313 \pm 29$ & 0 & 0 \\
\hline Palmyridae & $267 \pm 47$ & $6 \pm 4$ & $30 \pm 10$ & $122 \pm 70$ & $56 \pm 26$ & 0 & 0 \\
\hline
\end{tabular}

sobranchs Trochidae, Obtortidae, Buccunidae, Nassariidae, Costellaridae, Conidae and Terebridae; the opisthobranch Retusidae; the bivalves Solemyidae, Montacutidae and Myochamidae; the scaphopod Siphonodentalidae and heart-urchins of the family Brissidae. The amphipod family Gammaridae was characteristic of middle shelf reef flats, while Platyischnopidae (amphipod), Ostracoda and Bodotriidae (cumacean) were consistently found in the lagoons. The deeper parts of these lagoons were characterized by the polychaetes Oweniidae (a tube-dweller) and Sigalionidae, the cumacean Diastylidae and the amphipods Haustoriidae and Phtisicidae (a caprellid). Tellinid bivalves were also characteristic of lagoons, both on middle and outer shelf reefs.

No single taxon was characteristic of the outer shelf reefs, the only taxa restricted to this locality were the gastropod families Mitridae, represented by a single individual from the lagoon, and Philinidae. All other taxa found here were also found on the middle shelf (with the exception of the Portunidae which were found on the inner shelf). The most notable feature of the outer shelf sites was that many taxa commonly occuring at the other localities were either rare or absent. The 2 polychaete families Nephtyidae and Palmyridae, though regularly occuring elsewhere, were characteristically absent (Table 6).

\section{Principal co-ordinate analysis}

The PCA (Fig. 5) was used to display the relationship between reefs at similar localities on the cross-shelf gradient. The first 3 axes account for $46 \%$ of the variance in the data $(\mathrm{I}=21 \%$, II $=15 \%, \mathrm{III}=10 \%)$.

Two sites sampled at the inshore Phillips Reef were similar to all but the reef flat site on Pandora Reef, which was more similar to the shallow middle shelf sites. Sites from comparable zones on the 2 middle shelf reefs (Rib and Lodestone) were very similar. However, there was a clear separation between Myrmidon (outer shelf) and the other reefs including the second outer shelf reef (Dip), which was intermediate between the middle shelf reefs and Myrmidon.

\section{Temporal effects}

Of 190 individual samples included in the classification $93 \%$ of the nearest neighbours were replicate samples from the same site and time, indicating greater differences within a site at different times than within a site at a single time. No samples were mis-classified into a different site group. Thus changes occur within the sediment fauna which are perceptible over periods of several months, though the overall pattern deter- 

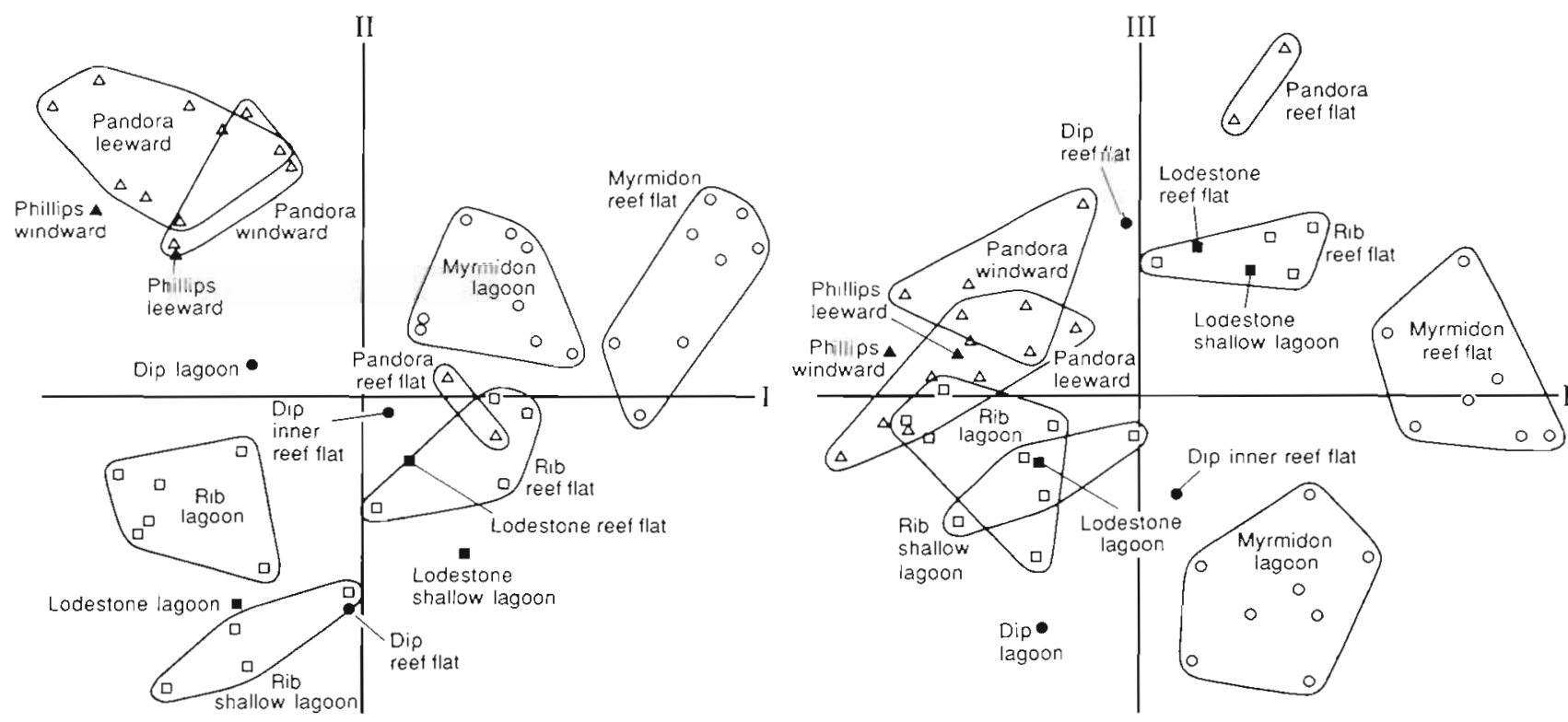

Fig. 5. Site groups from Pandora ( $\Delta$ ), Rib $(\square)$ and Myrmidon $(0)$ Reefs on Axes I and II and I and III of a principal coordinate analysis (enclosed by solid lines), and position of sampling sites from Phillips ( $\mathbf{\Lambda}$ ), Lodestone ( $\bullet$ ) and Dip ( $\bullet$ ) Reefs on the same axes

mined by position on the continental shelf and by environmental conditions within reefs was maintained throughout the sampling period. Classification using the Bray-Curtis coefficient on logarithmically transformed data assigns greater weight to qualitative differences in the fauna than to relative abundance. A further classification was performed with the BrayCurtis coefficient on raw data, a strategy more sensitive to changes in relative abundance. With this strategy only $73 \%$ of nearest neighbours were replicate samples from the same site and many samples were misclassified, indicating that temporal effects were due more to differences in relative abundance than to qualitative changes in the fauna.

\section{DISCUSSION}

Patterns in the distribution of sediment communities of the central GBR are apparent at several scales:

Cross-shelf differences $>$ Differences between zones within a reef $>$ Differences between reefs within a locality on the shelf $>$ Temporal differences within a site.

\section{Cross-shelf differences}

Position on the continental shelf accounts for the greatest differences in the sediment fauna. The sediment environment of the inner shelf reefs is markedly different from that of the middle and outer shelf and supports a fauna which is also markedly different. The sediment communities of the inner shelf are more diverse at a family level than those of the other reefs. This finding contrasts with previous studies along the transect, all of which found lowest diversity on the inner shelf reefs. These studies attribute low diversity to reduced diversity of habitat (Hammond et al. 1985, holothurians), reduced availability of food (Russ 1984a, herbivorous fishes) and to high turbidity (Dinesen 1983, soft corals). None of these factors appear to apply to sediments from inner shelf reefs. The sediments are less sorted than those of the middle and outer shelf reefs suggesting a greater diversity of micro-habitats at the scale of individuals animals. Organic carbon levels are higher and turbidity levels are of little consequence to burrowing animals.

The large differences between the middle and outer shelf reefs were unexpected. Zones of similar sediment type were found on reefs from both localities on the shelf and were expected to support similar communities. This did not prove to be the case. Diversity was lower on the outer shelf, most families found there being also represented on the middle shelf reefs and many taxa common on the middle shelf being rare or absent on the outer shelf. Lower diversity on outer shelf reefs has been observed for the hard corals (Done 1982); fishes (Williams \& Hatcher 1983) and holothurians (Hammond et al. 1985); while Russ (1984a, b) recorded significant cross-shelf differences in composition of herbivorous fish communities. The soft corals (Dinesen 1983) are the only group not to exhibit major differences in composition or diversity between middle and outer shelf reefs. 


\section{Within-reef differences}

Zonation of sediment fauna within reefs was related to degree of exposure and sediment type. On the inner shelf the sites protected by the cay at Pandora Reef differed from the windward site and from both the sites on Phillips Reef, which provides little shelter because of its small size and absence of cay or reef flat. On middle and outer shelf reefs the medium to fine lagoon sands supported a fauna significantly different from that of the coarse sand and gravel on the reef flat. There was also a trend for diversity to be higher in the lagoon.

The zonation of sediment communities within reefs was subordinate to the effect of location on the shelf i. e. different zones within a reef were more similar to each other than to the same zone on another reef from a different position on the continental shelf. This result contrasts with the findings for the other animal groups studied on this transect. All studies showed major differences between the inner reefs and those of the middle and outer shelf. Soft corals did not show differences in composition between middle and outer shelf reefs (Dinesen 1983). Herbivorous fishes (Russ 1984a) and corals (Done 1982) exhibited greater differences between zones within reefs than between middle and outer shelf reefs. Holothurians showed major cross shelf differences but generalised zonation patterns within reefs were not detected (Hammond et al. 1985).

\section{Within-locality differences}

Differences between similar zones from different reefs at the same locality on the shelf were mostly slight. Notable exceptions were the inner and outer reef flat communities from Dip Reef (outer shelf) which were more similar to the reef flat communities of the middle shelf reefs than to those of the other outer shelf reef (Myrmidon). Other studies suggest that Dip Reef has closer affinities to the middle shelf reefs than to Myrmidon (Wilkinson \& Trott 1985) and that Myrmidon. is more similar to reefs sited on the extreme edge of the continental shelf in the northern section of the GBR (Pichon pers. comm.). Myrmidon is geographically isolated on a projection of the continental shelf into the Coral Sea (Fig. 1) and may be isolated reproductively. In contrast Dip Reef is closer to the main body of the Great Barrier Reef and is more likely part of the general reproductive pool.

The only true reef sediment ( $>90 \%$ carbonate) on the inner shelf reefs supported a fauna similar to that of shallow middle shelf sediments. This indicates that differences between the fauna of the inner and middle shelf reefs are more attributable to sediment type than to locality.

\section{Temporal differences}

Communities at all sites showed slight changes between sampling occasions, most of which were attributable to differences in relative abundances Qualitative differences within a site were slight and the major patterns across the shelf and within reefs were maintained throughout the year-long sampling period. The sampling period covered several generations of the small, short-lived animals of the sediment and the persistence of the major patterns throughout this period indicates that populations are maintained from one generation to the next.

\section{Causes of patterns}

The various scales of pattern suggest that several inter-related processes may contribute to the establishment and maintenance of differences. In shallow tropical seas most infaunal species have a pelagic larval phase (Mileikovsky 1971) as the dispersal agent for the more or less sedentary adults. Processes acting on larvae or recently settled post-larvae are likely to determine observed patterns. Two hypotheses have been suggested to explain patterns of corals across the GBR (Done 1982): (1) differences are the result of differential availability of larvae (i.e. determined before settlement); (2) differences are the result of differential postsettlement survival (i.e. determined after settlement). In addition, active processes of habitat selection and preferential settlement (i.e. determination at settlement) have been suggested to explain patterns of fish on coral reefs (Williams \& Hatcher 1983).

All 3 mechanisms may have a role in determining the character of sediment communities. The central GBR is subject to longshore currents which may restrict larval dispersion across the shelf (Williams et al. 1984). Relatively small differences in sea temperature across the continental shelf (Pickard et al. 1977) may significantly reduce the probability of survival to metamorphosis (Thorson 1966). Both processes act on the pre-settlement phase and are on scales commensurate with the observed cross-shelf differences; their effect may also vary with time causing temporal changes in the fauna. Sediment type is crucial at the settlement and postsettlement stages. Delay of metamorphosis is widespread amongst benthic infauna presented with an unsuitable substratum (Wilson 1952, Butman 1987). Survival after settlement will be dependent on various biological and environmental factors all ultimately related to sediment type. Sediment structure and poresize will define the environment and will largely control the biological pressures to which the animals are subject. As a result the effects of habitat selection and 
differential post-settlement survival will be on the same scales as differences in sediment type.

These general processes may account for the observed patterns as follows: the very different sediment found on the inner shelf reefs (high silt/clay content) was certainly the major cause of the differences between the fauna from these and the other reefs. Where calcareous sediment was found on the inner shelf reefs, it supported a community similar to that of the middle shelf indicating that given a suitable sediment a community more typical ot the other reefs can develop on the inner shelf.

Differential larval availability is the simplest explanation for the difference between the middle and outer shelf sediment communities. The virtual absence of amphipods on the outer shelf, in contrast to their dominance on the middle shelf, may reflect a particular life history trait. The amphipods, and other peracarids, differ from most other benthic animals in brooding their young through the larval stages, a characteristic favouring short-range dispersion (Hermans 1979) and the consolidation of local populations. Their low numbers on the outer reefs may thus indicate a barrier to recruitment which does not affect animals which disperse by long-lived planktonic larvae. The most abundant and ubiquitous group, the syllids, have the capacity to reproduce both sexually with the production of planktonic larvae after pelagic swarming and asexually, by budding and fragmentation (Grassle \& Grassle 1974), a combination which facilitates widespread dispersal and the consolidation of populations.

Differences between reefs within a locality on the shelf and temporal changes within sites probably reflect elements of both larval recruitment and short-term fluctuations in abundance of established populations.

This is the first survey of the sediment fauna from coral reefs to consider environmental factors on a broad scale. Patterns persistent over time were identified at scales ranging from zones within reefs to localities of reefs across the width of the continental shelf. Mechanisms maintaining these patterns were suggested but have not been tested though they do lend themselves to controlled experimental investigation. Sediment animals, because of their short generation time and the variety of life history tactics, permit consideration of spatial pattern and temporal stability over time-scales that are amenable to the practicalities of research. Such an experimental approach may be illuminating to questions concerning the establishment and maintenance of coral reef communities in general.

Acknowledgements. This study was supported by a Postdoctoral Research Fellowship at the Australian Institute of Marine Science. The assistance of the following people is gratefully acknowledged: $T$ Done and $C$. Wilkinson for reading and criticising the manuscript; P. Eden and J. Sharpe of the RV
'Sirius' and K. Weaver for assistance in the field; I. Loch, W. F. Ponder $W$. B. Rudman, $T$ Cochran and S. Slacksmith for identification of the molluscs.

\section{LITERATURE CITED}

Abel, D. J., Williams, W. T., Williams, D. M. (1985). A fast classificatory algorithm for large problems under the BrayCurtis measure. J. exp. mar. Biol. Ecol. 89: 237-245

Aller, R. C., Dodge, R. E. (1974). Animal-sediment relations in a tropical lagoon Discovery Bay, Jamaica. J. mar Res. 32: 209-232

Alongi, D. M. (1986). Population structure and trophic composition of the free-living nematodes inhabiting carbonate sands of Davies Reef, Great Barrier Reef, Australia. Aust. J. mar Freshwat. Res. 37: 609-619

Ansell, A. D., McLusky, D. S., Stirling, A., Trevallion, A. (1978). Production and energy flow in the macrobenthos of two sandy beaches in South West India. Proc. R. Soc. Edinb. 76: 269-296

Bailey-Brock, J. H. (1976). Habitats of tubicolous polychaetes from the Hawaiian Islands and Johnston Atoll. Pacif. Sci. 30: $69-81$

Belbin, L. (1987). PATN Pattern analysis package reference manual. CSIRO Division of Wildlife and Rangelands Research, Canberra

Butman, C. A. (1987). Larval settlement of soft-sediment invertebrates: the spatial scales of pattern explained by active habitat selection and the emerging role of hydrodynamical processes. Oceanogr. mar. Biol. A. Rev. 25: $113-165$

Chardy, P., Clavier, J., Gerard, P., Laboute, P., Martin, A., Richer de Forges, B. (1987). Etude quantitative du lagon sud-ouest de Nouvelle Calédonie. Liste taxonomique, densités et biomasses. Rapp. Sci. Tech. ORSTOM Noumea 44: 1-81

Dinesen, Z. D. (1983). Patterns in the distribution of soft corals across the central Great Barrier Reef. Coral Reefs 1: $229-236$

Done, T. J. (1982). Patterns in the distribution of coral communities across the central Great Barrier Reef. Coral Reefs 1. $95-107$

Faubel, A. (1984). On the abundance and activity pattern of zoobenthos inhabiting a tropical reef area, Cebu, Philippines. Coral Reefs 3: 205-213

Flood, P. G., Orme, G. R. (1977). A sedimentation model for platform reefs of the Great Barrier Reef, Australia. Proc. IIIrd Int. Coral Reef Symp. 2: 111-116

Folk, R. L. (1974). Petrology of sedimentary rocks. Hemphills, Austin, Texas

Gower, J. C. (1967). Multivariate analysis and multi-dimersional geometry. Statistician 17: 13-28

Grassle, J. F., Grassle, J. P. (1974). Opportunistic life histories and genetic systems in marine benthic polychaetes. $\mathrm{J}$. mar. Res. 32: 253-285

Guerin-Ancey, O. (1970). Etude des intrusions terrigènes fluviatiles dans les complexes récifaux: délimitation et dynamique des peuplements des vases et des sables vaseux du chenal post récifal de Tuléar ( $\mathrm{S}$. W. de Madagascar). Rec. Trav. Stn mar. Endoume, Suppl. 10: 3-46

Hammond, L. S., Birtles R. A., Reichelt, R. E. (1985). Holothuroid assemblages on coral reefs across the central section of the Great Barrier Reef. Proc. Vth. Int. Coral Reef Congr 5: 285-290

Harrison, J. T. (1986). Recent marine studies at Enewetak, Atoll, Marshall Islands. Bull mar. Sci. 38: 1-3 
Hatcher, B. G. (1983). The role of detritus in the metabolism and secondary production of coral reef ecosystems. In: Baker, J. T. et al. (eds.) Proceedings Inaugural Great Barrier Reef Conference, Townsville, 28 Aug-2 Sep 1983. JCU Press, Townsville, p. 317-324

Hermans, C. O. (1979). Polychaete egg sizes, life histories and phylogeny. In: Stancyk, S. E. (ed.) Reproductive ecology of marine invertebrates. University of South Carolina Press Columbia, p. 1-9

Jones, A. R. (1984). Sedimentary relationships and community structure of benthic crustacean assemblages of reef-associated sediments at Lizard Island, Great Barrier Reef. Coral Reefs 3: 101-111

Kohn, A. J., Lloyd, M. C. (1973). Marine polychaete annelids of Easter Island. Int. Revue ges. Hydrobiol. 58: 691-712

Mileikovsky, S. A. (1971). Types of larval development in marine bottom invertebrates, their distribution and ecological significance: a re-evaluation. Mar. Biol. 10: 193-213

Pickard, G. L., Donguy, J. R., Henin, C., Rougerie, F. (1977). A review of the physical oceanography of the Great Barrier Reef and Western Coral Sea. Australian Institute of Marine Science Monograph Serie 2: 1-134

Reichelt, R. (1979). Infaunal polychaetes of reef crest habitats of Heron Island, Great Barrier Reef. Micronesica 15: $297-307$

Riddle, M. J. (1988). Density of sediment living animals from reefs across the central Great Barrier Reef. AIMS data report No. 1988.1. Australian Institute of Marine Science, Townsville

Russ, G. (1984a). Distribution and abundance of herbivorous grazing fishes in the central Great Barrier Reef. 1. Levels of variability across the entire continental shelf. Mar. Ecol. Prog. Ser. 20: 23-34

Russ, G. (1984b). Distribution and abundance of herbivorous grazing fishes in the central Great Barrier Reef. II. Patterns of zonation of mid-shelf and outershelf reefs. Mar. Ecol. Prog. Ser. 20: 35-44

Sandland, R. L., Young, P. C. (1979a). Probabilistic tests and stopping rules associated with hierarchical classification techniques. Aust. J. Ecol. 4: 399-406

Sandland, R. L., Young, P. C. (1979b). Tables of probabilities associated with the fission of replicate samples in classification. CSIRO Aust. Div. Fish. Oceanogr Rep. 108
Sandstrom, M. W., Tirendi, F., Nott, A. (1986). Direct determination of organic carbon in modern reef sediments and calcareous organisms after dissolution of carbonate. Mar. Geol. 70: 321-329

Santos, S. L., Simon, J. L. (1980). Marine soft-bottom community establishment following annual defaunation: larval or adult recruitment? Mar. Ecol. Prog. Ser. 2: 235-241

Thomassin, B. (1978). Soft-bottom communities. In: Stoddart, D. R., Johannes, R. E. (eds.) Coral reefs: research methods. UNESCO Monographs on oceanographic methodology 5 , Paris, p. 263-298

Thomassin, B., Vivier, M. H., Vitiello, P. (1976). Distribution de la méiofaune et de la macrofaune des sables coralliens de la retenue d'eau épirécifale du Grand Récif de Tuléar (Madagascar). J. exp. mar. Biol. Ecol. 22: 31-53

Thorson, G. (1966). Some factors influencing the recruitment and establishment of marine benthic communities. Neth. J. Sea Res. 3: 267-293

Wilkinson, C. R., Trott, L. A. (1985), Light as a factor determining the distribution of sponges across the central Great Barrier Reef. Proc. Vth Int. Coral Reef Congr. 5: 125-130

Williams, D. MdB. (1982). Patterns in the distribution of fish communities across the central Great Barrier Reef. Coral Reefs 1: $35-43$

Williams, D. MCB. (1983). Longitudinal and latitudinal variation in the structure of reef fish communities. In. Baker, J. $\mathrm{T}$ et al. (eds.) Proceedings: Inaugural Great Barrier Reef Conference, Townsville, 28 Aug-2 Sep 1983. JCU Press, Townsville, p. 265-270

Williams, D. McB., Hatcher, A. I. (1983). Structure of fish communities on outer slopes of inshore, mid-shelf and outer-shelf reefs of the Great Barrier Reef. Mar. Ecol. Prog. Ser. 10: 239-250

Williams, D. McB., Wolanski, E., Andrews, J. C. (1984). Transport mechanisms and the potential movement of planktonic larvae in the central region of the Great Barrier Reef. Coral Reefs 3: 229-236

Williams, W. T (1971). Principles of clustering. Ann. Rev. Ecol Syst. 2: 303-326

Wilson, D. P. (1952). The influence of the nature of the substratum on the metamorphosis of the larvae of marine animals, especially the larvae of Ophelia bicornis Savigny. Annls Inst. oceanogr., Monaco, N.S. 27:49-156 